\title{
Alzheimer Precursor Protein Interaction with the Nogo-66 Receptor Reduces Amyloid- $\beta$ Plaque Deposition
}

\author{
James H. Park, ${ }^{1}$ David A. Gimbel, ${ }^{1}$ Tadzia GrandPre, ${ }^{1}$ Jung-Kil Lee, ${ }^{1}$ Ji-Eun Kim, ${ }^{1}$ Weiwei Li, ${ }^{2}$ Daniel H. S. Lee, ${ }^{2}$ and \\ Stephen M. Strittmatter ${ }^{1}$ \\ ${ }^{1}$ Department of Neurology, Yale University School of Medicine, New Haven, Connecticut 06510, and 2BiogenIdec Inc., Cambridge, Massachusetts 02140
}

\begin{abstract}
Pathophysiologic hypotheses for Alzheimer's disease $(\mathrm{AD})$ are centered on the role of the amyloid plaque $\mathrm{A} \beta$ peptide and the mechanism of its derivation from the amyloid precursor protein (APP). As part of the disease process, an aberrant axonal sprouting response is known to occur near A $\beta$ deposits. A Nogo to Nogo-66 receptor (NgR) pathway contributes to determining the ability of adult CNS axons to extend after traumatic injuries. Here, we consider the potential role of NgR mechanisms in AD. Both Nogo and NgR are mislocalized in AD brain samples. APP physically associates with the NgR. Overexpression of $\mathrm{NgR}$ decreases $\mathrm{A} \beta$ production in neuroblastoma culture, and targeted disruption of $\mathrm{NgR}$ expression increases transgenic mouse brain $\mathrm{A} \beta$ levels, $\mathrm{A} \beta$ plaque deposition, and dystrophic neurites. Infusion of a soluble $\mathrm{NgR}$ fragment reduces $\mathrm{A} \beta$ levels, amyloid plaque deposits, and dystrophic neurites in a mouse transgenic $\mathrm{AD}$ model. Changes in NgR level produce parallel changes in secreted APP $\alpha$ and A $\beta$, implicating NgR as a blocker of secretase processing of APP. The $\mathrm{NgR}$ provides a novel site for modifying the course of AD and highlights the role of axonal dysfunction in the disease.
\end{abstract}

Key words: Alzheimer's disease; $\beta$-amyloid plaque; Nogo; transgenic mice; Nogo-66 receptor; gene targeting; amyloid precursor protein; APP

\section{Introduction}

Amyloid plaques and neurofibrillary tangles are the principal pathologic hallmarks that accompany neuronal loss in the dementia of Alzheimer's disease (AD) (Hardy and Selkoe, 2002; Selkoe and Schenk, 2003). The amyloid A $\beta$ peptide is derived proteolytically from amyloid precursor protein (APP) and is the major constituent of the amyloid plaque in $\mathrm{AD}$. Although the rate of $\mathrm{A} \beta$ peptide release from APP is implicated in AD pathophysiology, there is less certainty regarding which forms of $A \beta$ result in neuronal dysfunction and by what mechanism this occurs. The transformation of monomeric $\mathrm{A} \beta$ to large amyloid plaque deposits proceeds through several intermediate steps, and intermediate forms may be causative in the neuronal dysfunction of AD (Klein, 2002; Walsh et al., 2002b). A $\beta$ peptides have been shown to interact with several macromolecules that might potentially contribute to pathology. Such A $\beta$-binding proteins include, but are not limited to, the receptor for advanced glycation end products (Yang et al., 1996), the low-affinity NGF receptor p75-NTR (Kuner et al., 1998) and nicotinic acetylcholine receptors (Wang et al., 2000; Dineley et al., 2001; Nagele et al., 2002). The cellular effects of $\mathrm{A} \beta$ application have included cell death, altered synap-

Received June 9, 2005; revised Dec. 4, 2005; accepted Dec. 15, 2005.

This work was supported in part by grants from the National Institutes of Health, the McKnight Foundation, and the Institute for the Study of Aging (S.M.S.) and by an Institutional Medical Scientist Training grant (J.H.P.). S.M.S. is a member of the Kavli Institute of Neuroscience at Yale University. We thank the Harvard Brain Tissue Resource Center for human brain tissue samples and S.S. Sisodia for helpful discussions, N2A-APPsw cells, and anti-C-terminal APP antibody 369.

Correspondence should be addressed to Stephen M. Strittmatter, Department of Neurology, Yale University School of Medicine, P.0. Box 208018, New Haven, CT 06510. E-mail: stephen.strittmatter@yale.edu.

DOI:10.1523/JNEUROSCI.3291-05.2006

Copyright $\odot 2006$ Society for Neuroscience $\quad$ 0270-6474/06/261386-10\$15.00/0 tic transmission, stimulation of neurite outgrowth, and inhibition of neurite outgrowth (Walsh et al., 2002a; Kamenetz et al., 2003). It remains unclear which cellular effects depend on specific molecular interactions and are most relevant to the ability of $\mathrm{A} \beta$ to cause dementia.

There are several observations that connect APP and A $\beta$ to axonal mechanisms. Many amyloid plaques, the so-called "neuritic plaques," exhibit a cluster of dystrophic neurites surrounding their edge (Lombardo et al., 2003). This suggests that aberrant, ineffective sprouting mechanisms are activated in the vicinity of $A \beta$ deposits. Recent data have demonstrated that local $\mathrm{A} \beta$ deposits are dependent on axonal input, implying that the principal source of $A \beta$ is peptide released from the presynaptic ending of the axon (Lazarov et al., 2002; Sheng et al., 2002). In brain trauma, APP accumulation in transected axons is one of the better markers of injured axons (Otsuka et al., 1991; Scott et al., 1991; Gentleman et al., 1993). Furthermore, APP has been implicated as an adaptor protein for kinesin I-based axonal transport (Kamal et al., 2001). Most recently, intriguing studies have demonstrated physical interactions between Reticulon family proteins (including Nogo) and BACE1 ( $\beta$-secretase activity of the $\beta$-site APP-cleaving enzyme), one of the proteases responsible for $\mathrm{A} \beta$ production from APP (He et al., 2004). For these reasons, we considered the potential connection between those molecular processes that regulate axonal sprouting in the adult CNS and the $\mathrm{APP} / \mathrm{A} \beta$ pathologic process. One pathway implicated in adult axonal CNS sprouting is the Nogo/Nogo receptor $(\mathrm{NgR})$ pathway (Chen et al., 2000; GrandPre et al., 2000, 2002; Prinjha et al., 2000; Fournier et al., 2001; Kim et al., 2003, 2004; Li and Strittmatter, 2003; McGee and Strittmatter, 2003; Lee et al., 2004; Li et al., 
a

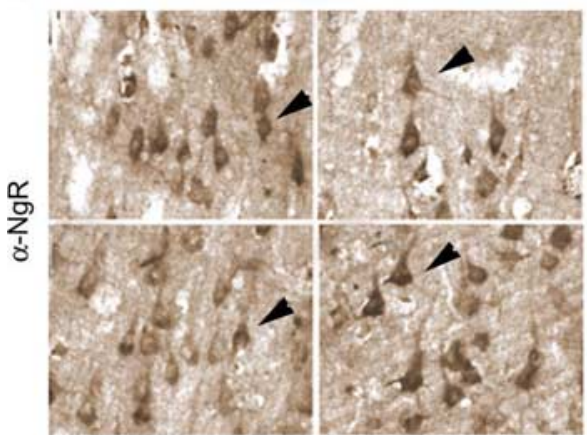

b

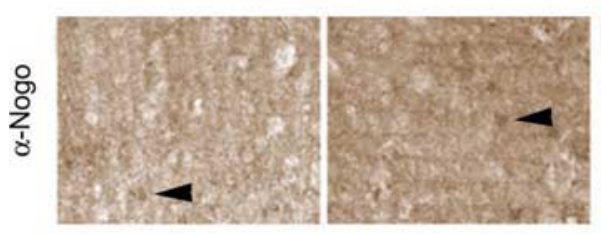

f
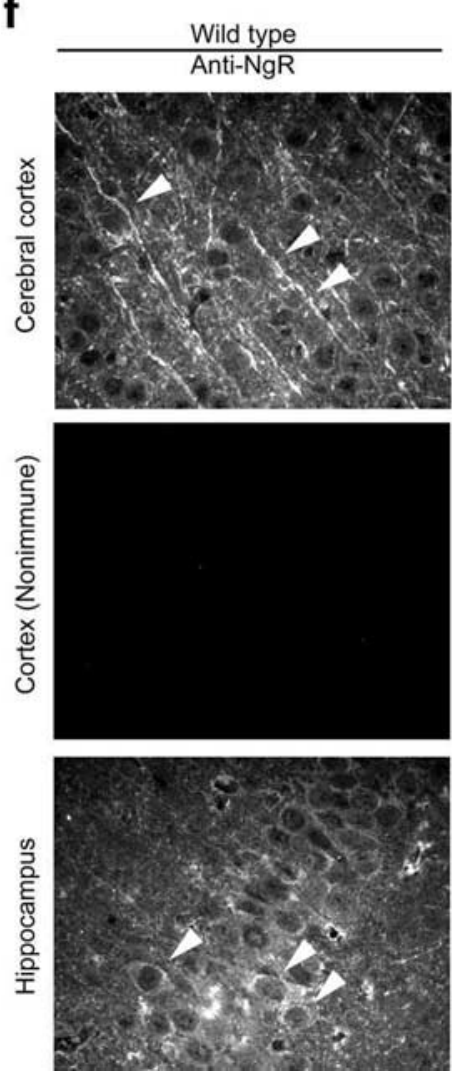

$A D$
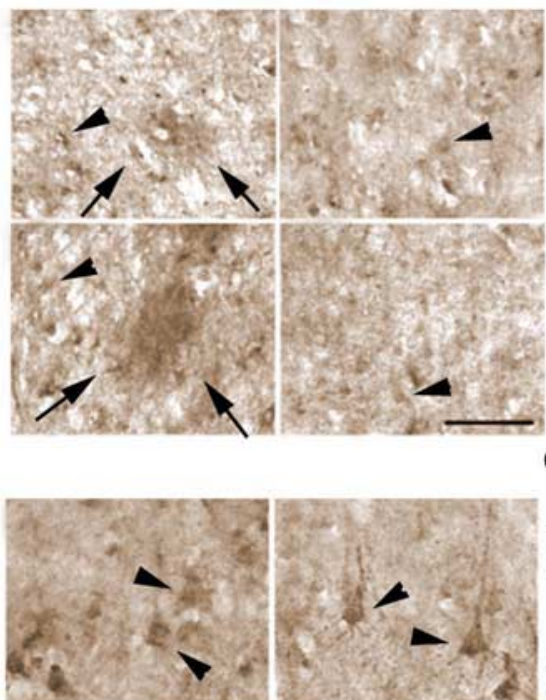

d

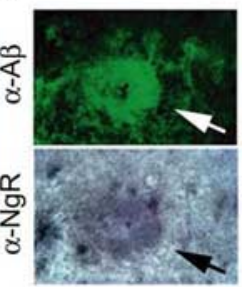

DLB

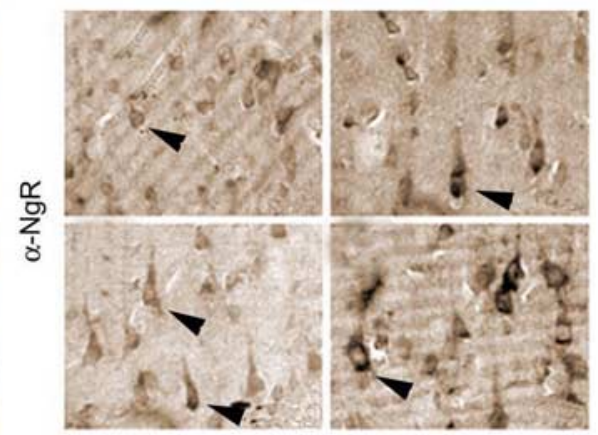

e
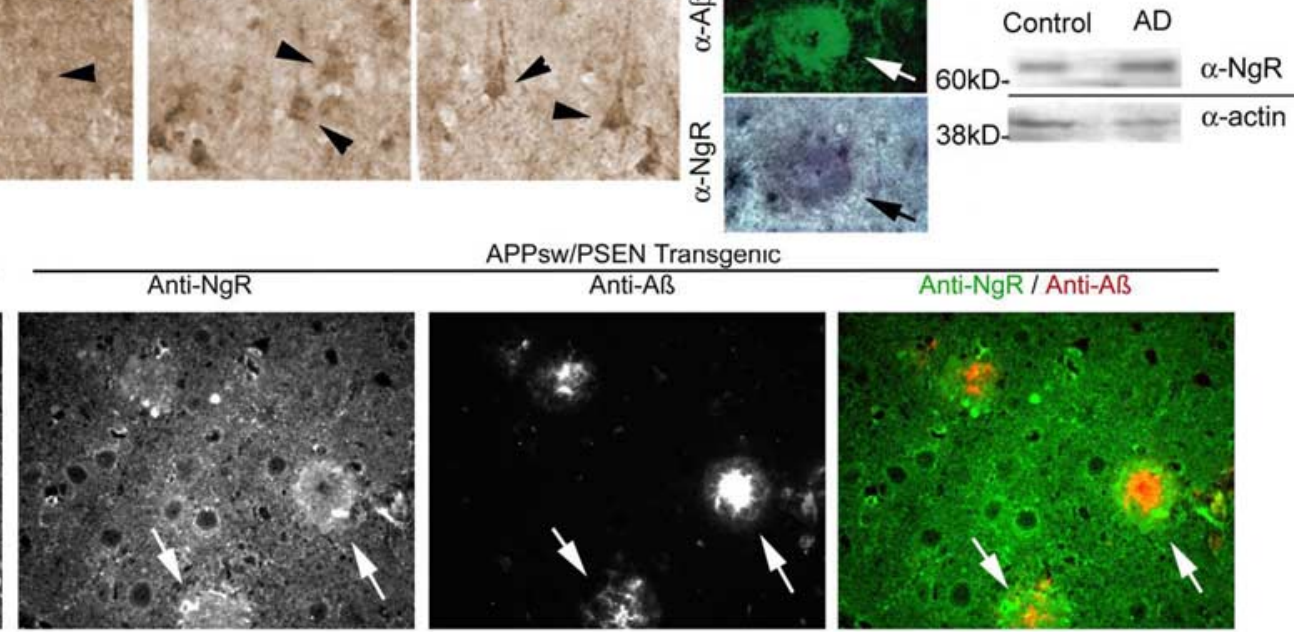

APPsw/PSEN Transgenic
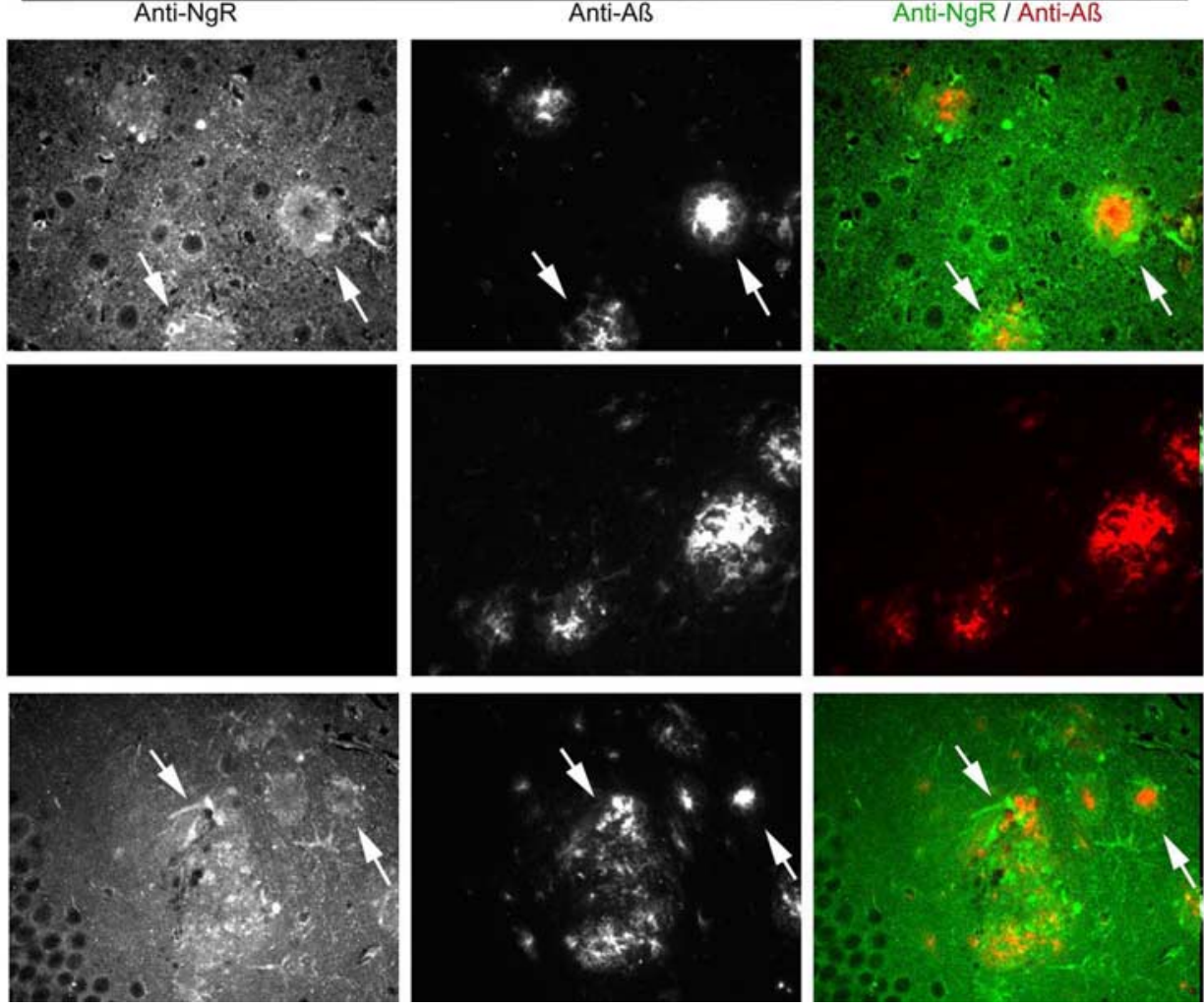

Figure 1. Altered Nogo and NgR localization in human AD brain. $\boldsymbol{a}-\boldsymbol{c}$, Human brain samples from age-matched control samples, AD, or diffuse Lewy body dementia (DLB) were processed for anti-NgR or anti-Nogo-A immunohistology as indicated. All samples are from the hippocampus. Note the reduced cellular NgR localization in AD and the enhanced cellular Nogo localization in the AD samples (arrowheads, cellular staining). Some amyloid plaques are $\mathrm{NgR}$ immunoreactive (arrows). $\boldsymbol{d}$, The colocalization of $\mathrm{NgR}$ and $\mathrm{A} \beta$ in plaques is shown in higher magnification at the bottom right (arrows).e, Anti-NgR immunoblot demonstrates the specificity of the anti-NgR antibody and the unchanged $\mathrm{NgR} \mathrm{level} \mathrm{in} \mathrm{the} \mathrm{AD} \mathrm{brain} \mathrm{compared} \mathrm{with} \mathrm{controls.} \mathrm{Two} \mathrm{additional} \mathrm{control} \mathrm{and} \mathrm{two}$ additional $A D$ cases had staining patterns similar to that shown here. Anti-actin immunoblot demonstrates similar protein loading. $f$, Sections of cerebral cortex or hippocampus from wild-type or APPswe/PSEN transgenic mice of 9 months age were stained with anti-NgR or nonimmune lgG (green in merged image) and anti-A $\beta$ antibody (6E10, red in merged image). Brains were fixed in paraformaldehyde, sectioned in paraffin, and treated with formic acid before staining. In wild-type brain, axonal profiles are detected in the cerebral cortex, and cell soma are stained in the hippocampus (arrowheads). In transgenic brain, cellular and axonal staining is reduced, but periplaque NgR immunoreactivity (arrows) is detected.

2004). We find that NgR interacts with APP and $\mathrm{A} \beta$ to limit $\mathrm{A} \beta$ accumulation in vivo.

\section{Materials and Methods}

Human brain tissue samples were obtained from the National Institutes of Health-supported Harvard Brain Tissue Resource Center with no per- sonal identifying information. Anti-Nogo-A and anti-NgR rabbit antibodies and immunohistological methods have been described previously (Wang et al., 2002), as have NgR expression vectors, alkaline phosphatase (AP)-Nogo-66 protein, and the purified soluble function-blocking NgR ectodomain [NgR(310)ecto-Fc] (GrandPre et al., 2000; Fournier et al., 2001, 2002; Lee et al., 2004; Li et al., 2004). The anti-NgR antibody raised 
in goat was from R \& D Systems (Minneapolis, $\mathrm{MN})$ (AF1440). The AP-A $\beta$ and AP-APP proteins were produced by the same method as AP-Nogo-66. The binding of AP fusion proteins to transfected COS-7 cells has been described previously (GrandPre et al., 2000; Fournier et al., 2001, 2002; Li et al., 2004). N2A neuroblastoma cells stably expressing the Swedish form of APP (APPswe) and the 369 anti-C-terminal-APP antibody were generous gifts from S. S. Sisodia (University of Chicago, Chicago, IL) (Thinakaran et al., 1996). The anti-N-terminal-APP 5228 antibody, the anti$\mathrm{A} \beta_{1-17}$ 6E10 antibody, and the anti-Cterminal-APP 5352 antibody were obtained from Chemicon (Temecula, CA). The anti-A $\beta$ 4G8 antibody and the anti-C-terminal-APP 51-2700 antibodies were from Signet Laboratories (Dedham, MA) and Zymed Laboratories (South San Francisco, CA), respectively. The anti-secretet APP (SAPP) $\beta$ swe-specific 6A1 antibody was from Immunobiological Laboratories (Gunma, Japan). $\mathrm{A} \beta_{1-40}$ and $\mathrm{A} \beta_{40-1}$ with an $\mathrm{N}$-terminal biotin tag were synthesized at the W. M. Keck Biotechnology facility at Yale University.

For covalent cross-linking studies, adult rat brain was homogenized in PBS plus protease inhibitor mixture (Roche Products, Welwyn Garden City, UK). The particulate fraction was collected by centrifugation at $100,000 \times g$ for $20 \mathrm{~min}$. Membranes were resuspended in PBS ( $1 \mathrm{ml} / \mathrm{gm}$ brain wet weight) and incubated with $3 \mathrm{~mm}$ bis(sulfosuccinimidyl) suberate $\left(\mathrm{BS}^{3}\right)$ for $1 \mathrm{~h}$ at $4^{\circ} \mathrm{C}$. Unreacted cross-linker was quenched by addition of Tris-HCl, $\mathrm{pH}$ 7.6, to $0.1 \mathrm{M}$. Particulate material was again collected by centrifugation, and then membrane protein was solubilized with $1 \%$ Triton $\mathrm{X}-100$. The detergent extract was subjected to nonimmune IgG or anti-NgR (1D9) immunoprecipitation using protein A/G Sepharose (Pierce, Rockford, IL) and analyzed by anti-NgR plus anti-APP immunoblot.

The generation of $\mathrm{NgR}^{-1-}$ mice has been described previously (Kim et al., 2004). In this line, exon II containing the entire mature coding region is deleted and no $\mathrm{NgR}$ protein is produced. In the studies here, the $\mathrm{NgR}$ mutant allele from a $129 / \mathrm{sv}$ embryonic stem cell was backcrossed to C57BL/6J for four to six generations before breeding with APPswe/ presenilin-1 (PSEN-1)( $\Delta$ E9) transgenic mice. In all experiments, littermate mice carrying one APPswe/PSEN-1( $\Delta \mathrm{E} 9)$ transgene and either heterozygous or homozygous for the $\mathrm{NgR}$ null mutation were compared with one another. Transgenic APPswe/PSEN-1( $\Delta$ E9) (Borchelt et al., 1997; Jankowsky et al., 2003) mice were from The Jackson Laboratory (Bar Harbor, ME) (stock \#04462) and were obtained on a mixed strain background as described by the provider.

$\mathrm{A} \beta$ ELISA assays were performed according to the instructions of the manufacturer (Biosource, Camarillo, CA). A $\beta$ plaques in parasagittal sections of $4 \%$ paraformaldehyde-fixed brain were detected immunohistologically with anti-A $\beta_{1-17} 6 \mathrm{E} 10$ antibody after $0.1 \mathrm{M}$ formic acid treatment for antigen recovery. Plaque area was quantitated using NIH Image as a percentage of total cerebral cortical area for three sections from each animal. Neuritic dystrophy was visualized by staining with monoclonal anti-synaptophysin antibodies (Sigma, St. Louis, MO) in parasagittal paraffin-embedded sections. The area of cerebral cortex and hippocampus occupied by clusters of dystrophic neurites was measured as a percentage of total area, using the outer border of increased staining by the same method as for $\mathrm{A} \beta$ plaque load. For analysis of sAPP $\alpha$ and $\mathrm{A} \beta$ levels from brain extracts, forebrain was extracted with $0.1 \mathrm{M}$ formic acid, neutralized with Tris, and clarified by centrifugation at $10,000 \times g$.
To administer $\mathrm{NgR}(310)$ ecto-Fc protein to mice, animals were anesthetized with isoflurane and oxygen, and a burr hole was drilled in the skull. A cannula (Alzet brain infusion kit II; Alza, Palo Alto, CA) was introduced into the right lateral ventricle at stereotaxic coordinates 0.6 $\mathrm{mm}$ posterior and $1.2 \mathrm{~mm}$ lateral to bregma and $2.0 \mathrm{~mm}$ deep to the pial surface. The cannula was held in place with cyanoacrylate, and the catheter was attached to a subcutaneous osmotic minipump (Alzet 2004; Alza). The pump delivered $0.25 \mu \mathrm{l} / \mathrm{h}$ for $28 \mathrm{~d}$ of a $1.2 \mathrm{mg} / \mathrm{ml}$ solution of $\mathrm{NgR}(310)$ ecto-Fc or rat IgG in PBS. Pumps were replaced after $28 \mathrm{~d}$ and connected to the same cannula.

\section{Results}

\section{Altered NgR and Nogo subcellular localization in AD}

As a first direct step toward considering a role for the Nogo-NgR system in $\mathrm{AD}$, human brain sections from $\mathrm{AD}$ cases and controls were examined histologically for Nogo-A and NgR localization (Fig. $1 a, b, d$ ). Tissue from the hippocampus and Brodmann's area 20/36 were examined in six control and six AD cases. In the control adult human brain, Nogo-A immunoreactivity is detectable in a diffuse granular pattern in the neuropil of these brain regions with little cellular staining. Here, we have focused on gray matter in which a majority of Nogo is neuronal, not oligodendrocytic in origin, as in white matter (Wang et al., 2002). In all of the $\mathrm{AD}$ cases, there is a dramatic shift of Nogo-A immunoreactivity to cell bodies (Fig. 1b, arrowheads). NgR localization in the AD brain is shifted in the opposite manner (Fig. 1a). In control cases, the highest concentration of the NgR protein is found in cell soma (arrowheads). Both the pattern of staining in human sam- 
a

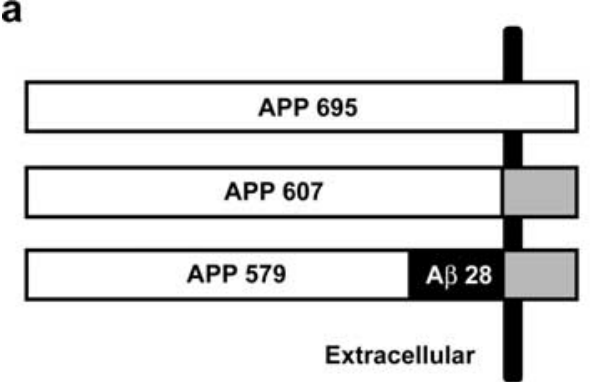

b
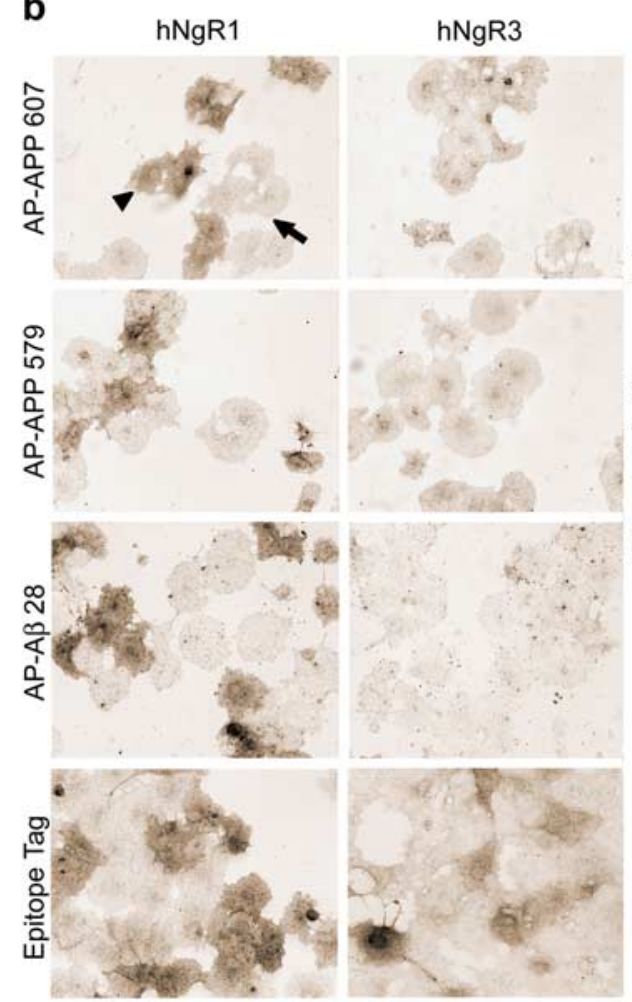

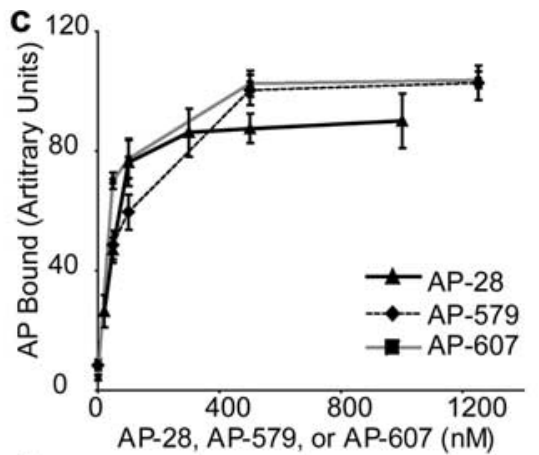

d
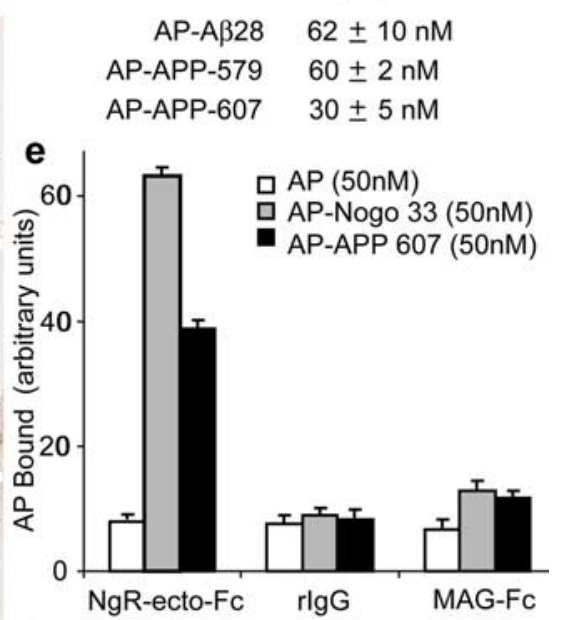

f

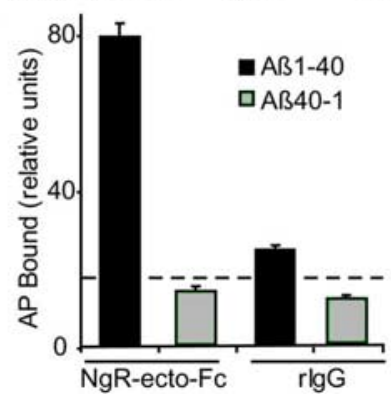

Figure 3. APP ectodomain binds to NgR1-expressing cells. $\boldsymbol{a}$, A schematic illustrates the cellular orientation of APP and the fragments that were used to express AP fusion proteins. $\boldsymbol{b}, \mathrm{COS}-7$ cells were cultured with transfection of human NgR1 or human $\mathrm{NgR3}$ expression plasmid, and their respective expressions were verified by epitope-tag immunohistology. Fifty nanomolar solutions of AP-APP607, AP-APP579, and A $\beta_{28}$-AP were allowed to bind to transfected cells for $2 \mathrm{~h}$ before washing, fixation, heat inactivation of endogenous AP, and enzymatic detection of bound fusion protein. Note the dark reaction product by arrowhead derived in cultures expressing $\mathrm{NgR} 1$ but not $\mathrm{NgR3}$. An untransfected cell is labeled by the arrow. This is one of five experiments with similar results. $\boldsymbol{c}, \boldsymbol{d}$, Binding of AP-A $\beta_{28}$, APP579, and APP607 to NgR1-expressing COS-7 cells from an experiment as in $\boldsymbol{a}$ was measured as a function of ligand concentration from 5 to $1250 \mathrm{~nm}$. Data are means \pm SEM from one of three experiments with similar results. The calculated $K_{d}$ is noted in d. $\boldsymbol{e}$, Purified NgR-ecto(310)-Fc, MAG-Fc, or BSA (100 ng of each protein) was coated onto microtiter wells. After blockade of nonspecific sites with excess BSA, the wells were exposed to $50 \mathrm{~nm} \mathrm{AP,} \mathrm{AP-Nogo} \mathrm{33,} \mathrm{or}$ AP-APP607. Data are the means \pm SEM from three similar experiments. Note the selective binding of either Nogo(1-33) or APP607 to NgR-coated wells. $f$, The binding of $100 \mathrm{~nm}$ biotin- $\mathrm{A} \beta_{1-40}$ or biotin- $\mathrm{A} \beta_{40-1}$ to immobilized $\mathrm{NgR}$ (344)ecto-Fc or lgG (100 ng of each protein) was detected by retention of streptavidin-AP.

ples and the previous murine studies suggest that the cellular $\mathrm{NgR}$ immunoreactivity is neuronal (Wang et al., 2002). Four AD brain samples exhibit little cellular NgR staining but diffuse immunoreactivity in the neuropil and in plaque-like deposits. Neither $\mathrm{NgR}$ nor Nogo-A colocalizes with neurofibrillary tangles or dystrophic neurites recognized by an antibody directed against hyperphosphorylated Tau protein (data not shown). Specificity of staining was demonstrated by antigen blockade and by the recognition of a single immunoreactive protein on immunoblots of human samples (Fig. $1 e$ and data not shown). By immunoblot analysis, the total level of $\mathrm{NgR}$ is not altered in $\mathrm{AD}$ samples (Fig. 1e). The absence of $\mathrm{NgR}$ staining in cell bodies is not attributable to a complete absence of neurons, as can be appreciated clearly in the adjacent sections stained with Nogo-A antibodies (Fig. 1, compare $a, b)$. Altered $\mathrm{NgR}$ localization is not observed in a different dementing illness, diffuse Lewy body dementia (Fig. 1c). In addition to the shift of $\mathrm{NgR}$ out of the cell soma, the protein is concentrated in amyloid plaques (Fig. 1a,d, arrows). Double immunohistochemistry for $\mathrm{A} \beta$ and $\mathrm{NgR}$ demonstrates their colocalization in these deposits (Fig. 1d). These findings suggest that the $\mathrm{Nogo} / \mathrm{NgR}$ pathway might have either a primary or secondary role in $\mathrm{AD}$ pathology.

We also examined $\mathrm{NgR}$ localization in a transgenic mouse model of $\mathrm{AD}$, the APPswe/PSEN-1( $\triangle \mathrm{E} 9)$ double-transgenic mice (Borchelt et al., 1997; Jankowsky et al., 2003). NgR-immunoreactive processes are prominent in the cerebral cortex (Fig. 1f, arrowheads, top left), whereas neuronal cell bodies are stained in the CA3 region of the hippocampus of wild-type mice (Fig. 1f, arrowheads, bottom left). $\mathrm{NgR}$ staining of cell bodies is less prominent in the transgenic mice (arrowheads), and axons are not readily apparent in the APPswe/PSEN-1( $\Delta \mathrm{E} 9)$ cerebral cortex. A fraction of the protein is detected at the border of amyloid plaques (Fig. $1 f$, arrows). $\mathrm{NgR}$ staining is most prominent at the circumference of intense $A \beta$ deposits (Fig. 1f, merged image). The transgenic mouse model confirms the existence of altered $\mathrm{NgR}$ localization in $\mathrm{AD}$.

\section{APP interacts with NgR in transfected cells and brain}

Based on these observations of Nogo and $\mathrm{NgR}$ localization, we considered whether there might be direct interactions between these proteins and APP. Epitope-tagged versions of the proteins were expressed in human embryonic kidney HEK-293T cells and immunoprecipitation studies were performed. APP specifically associates with NgR (Fig. 2a) but not with Nogo-A in these studies (data not shown). If APP and $\mathrm{NgR}$ are to associate in living cells, then at least a portion of the proteins must colocalize at the subcellular level. Both proteins are known to be associated with lipid rafts (Fournier et al., 2002; Ehehalt et al., 2003), and double-immunohistochemical studies reveal a nearly complete overlap of the distribution for two proteins in transfected cells and primary neurons (Fig. $2 b, c)$. The physical association of endogenous $\mathrm{NgR}$ and APP was also examined in rat brain homogenates. Immunoprecipitates of APP contain $\mathrm{NgR}$ immunoreactivity, and anti-NgR isolates possess APP 
protein detected with different APP antibodies (Fig. $2 d$ ). To verify that the physical association of $\mathrm{NgR}$ with APP occurs within intact tissue and is not dependent on detergent solubilization, covalent cross-linking studies of rat brain membranes were performed (Fig. 2e). Approximately half of $\mathrm{NgR}$ is covalently coupled by $\mathrm{BS}^{3}$ treatment into a highmolecular-weight complex with an apparent molecular weight $\left(M_{\mathrm{r}}\right)$ of 200-250 $\mathrm{kDa}$. The high $M_{\mathrm{r}}$ NgR-immunoprecipitable complex is also strongly immunoreactive for APP. The apparent molecular mass of this complex is greater than would be predicted for a 1:1 NgR/APP complex and may reflect aberrantly slow migration of a cross-linked complex or the presence of a more complicated structure including two copies of $\mathrm{NgR}$ or additional protein species. We conclude that a fraction of APP and NgR are physically associated within neurons.

We sought to determine which region of APP might interact with NgR. Because $\mathrm{NgR}$ is a glycophosphatidylinositol (GPI)anchored protein, any direct interaction must be mediated by the APP extracellular (ecto) domain. We created fusion proteins containing various portions of the APP ectodomain fused to AP. At nanomolar concentrations, the ecto-APP-AP protein binds to NgR-expressing COS cells but not to vector-transfected COS cells or to COS cells expressing the related protein NgR3 (Fig. 3). The APP extracellular domain is cleaved by $\beta$-secretase enzyme into two fragments. As AP fusion proteins, the sAPP $\beta$ fragment (APP597) and $\mathrm{A} \beta_{1-28}$ ectodomain fragment both exhibit affinity for $\mathrm{NgR}$ (Fig. $3 b-d$ ). Thus, the physical interaction of APP with NgR occurs through both amino and carboxyl segments of the ectodomain of APP. Furthermore, both $\beta$-secretase substrates (APP607) and $\beta$-secretase products (APP597 and A $\beta_{1-28}$ ) can interact with $\mathrm{NgR}$.

The association of APP and NgR might be direct or indirect. To distinguish these possibilities, we immobilized purified NgR protein and examined the binding of APP-AP ligand in the absence of other cellular constituents (Fig. 3e). The APP ligand clearly binds to NgR under these minimal conditions, demonstrating a direct association of the two proteins.

The AP fusion method required a truncated $\mathrm{A} \beta_{1-28}$ fragment to maintain protein ligand solubility. We used synthetic forms of $\mathrm{A} \beta_{1-40}$ to verify that the endogenous peptide also interacts with $\mathrm{NgR}$. In the ELISA format, the interaction of biotin-A $\beta_{1-40}$ with $\mathrm{NgR}$ is easily measured above background (Fig. $3 f$ ). In contrast, the reverse $\mathrm{A} \beta_{40-1}$ peptide does not interact with immobilized NgR. A $\beta_{1-40}$ binding to cell surface $\mathrm{NgR}$ was examined using biotinylated peptide, fluorescent avidin, and cell sorting (Fig. 4). The binding of $A \beta_{1-40}$ to COS-7 cells is dramatically enhanced by $\mathrm{NgR}$ expression, and this binding is suppressed by anti-NgR anwith similar results.
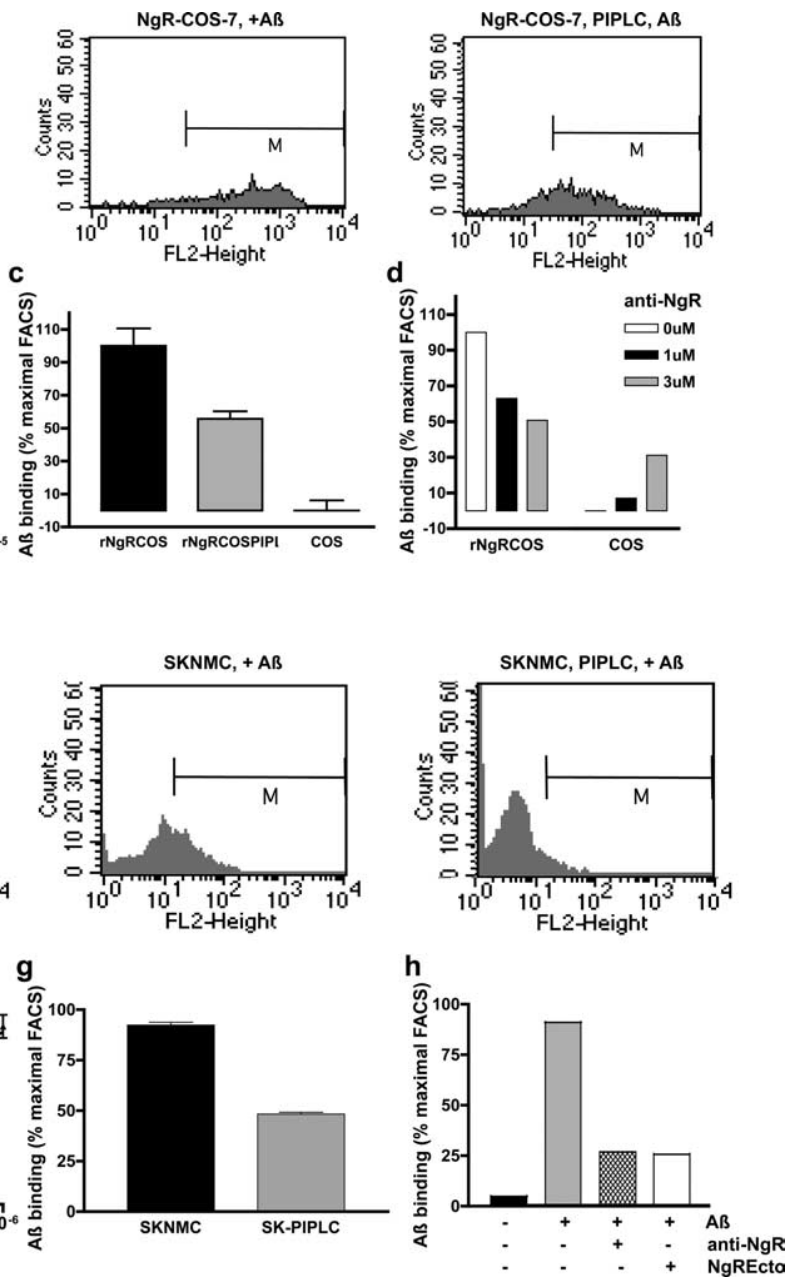

Figure 4. $\mathrm{A} \beta_{1-40}$ binds to $\mathrm{NgR}$-expressing cells. $\boldsymbol{a}-\boldsymbol{d}$, Binding of $100 \mathrm{~nm}$ biotinylated $\mathrm{A} \beta_{1-40}$ to COS-7 cells transfected with vector or rat NgR expression plasmid. Bound $A \beta$ was detected by fluorescence-activated cell sorting (FACS) after incubation with - Some cells were treated with $1 \mathrm{U}$ of PI-PLC for $1 \mathrm{~h}$ at $37^{\circ} \mathrm{C}$ to release GPI-anchored proteins $M$. The dose dependence for binding was assessed with the indicated concentrations of $A \beta(\boldsymbol{b})$. The NgR1 antibody 7 E11 was cell sorting method was used to detect biotin-A $\beta_{1-40}$ binding to human neuroblastoma SKNMC cells $(\boldsymbol{e})$. A $\beta_{1-40}$ bound dose ependently $(\boldsymbol{f})$ and the binding was diminished after PI-PLC treatment $(\boldsymbol{e}, \boldsymbol{g}) \cdot \boldsymbol{h}$, Biotinylated A $\beta_{1-40}$ was displaced from SKNMC by anti-NgRantibodies $(2 \mathrm{E} 10,1 \mu \mathrm{M})$ and by soluble $\mathrm{NgR}(344)$ ecto- $\mathrm{Fc}(1 \mu \mathrm{M})$. Data are means $\pm \mathrm{SEM}$ from three to six experiments

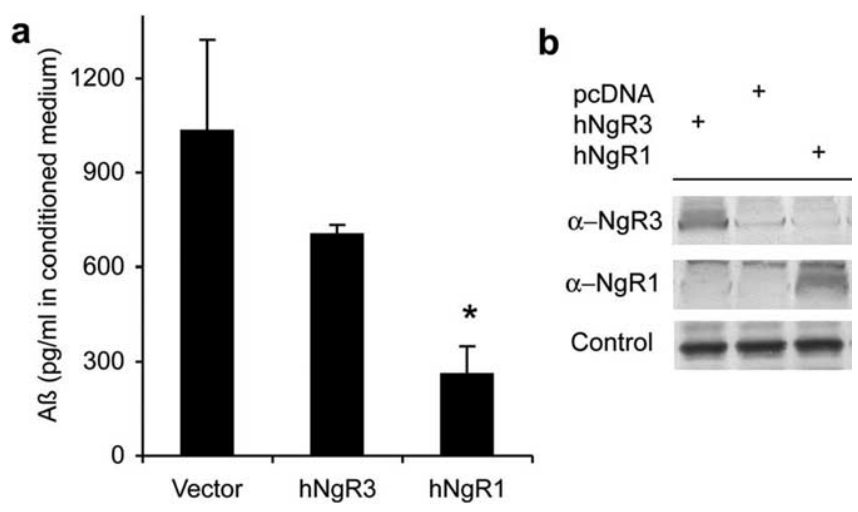

Figure 5. $\mathrm{NgR}$ expression decreases $A \beta$ formation by neuroblastoma cells. Neuroblastoma N2A cells stably expressing APPswe (Thinakaran et al., 1996) were transiently transfected with control plasmid or vectors directing the expression of $h N g R 3$ or $h N g R 1 . a, A \beta_{1-40}$ ELISA was performed on conditioned medium. ${ }^{*} p \leq 0.025$; the decrease in $A \beta$ is significant and represents data from four independent transfections. $\boldsymbol{b}$, N2A cell lysate was examined by immunoblot with the indicated antibodies to verify expression. 


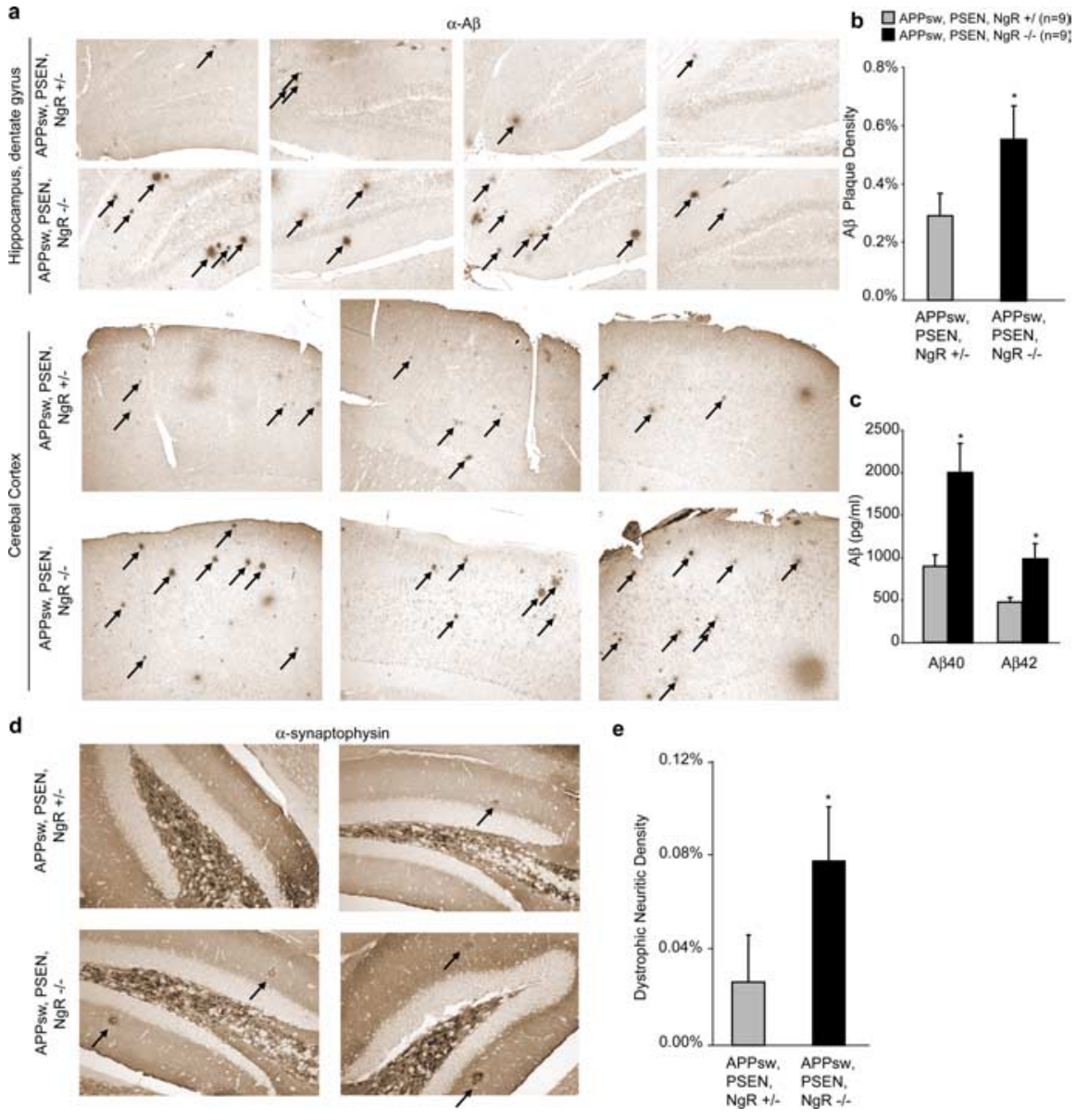

Figure 6. Enhanced $A \beta$ and neuritic dystrophy in FAD transgenic mice lacking $\mathrm{NgR}$. Mice coexpressing human APPswe/PSEN$1(\Delta \mathrm{E} 9)$ and heterozygous for a null allele of $\mathrm{NgR}$ were intercrossed with $\mathrm{NgR} \mathrm{R}^{-/-}$mice. At 6 months of age, littermate-matched mice expressing APPswe/PSEN-1( $\triangle \mathrm{E} 9)$ and either $\mathrm{NgR}^{+/-}$or $\mathrm{NgR}^{-/-}$were killed. Brain tissue was analyzed by immunohistochemistry and ELISA. $\boldsymbol{a}, \boldsymbol{b}$, Arrows indicate examples of plaque deposits in hippocampal dentate gyrus and cerebral cortex. Plaque densities were quantified from nine mice in each group and are significantly different ( ${ }^{*} p \leq 0.05$, Student's $t$ test). $c, A \beta_{1-40}$ and $A \beta_{1-42}$ levels were assessed by ELISA and are significantly different $\left({ }^{*} p \leq 0.04\right.$ level, Student's $t$ test) for nine mice of each genotype. $\boldsymbol{d}, \boldsymbol{e}$, Anti-synaptophysin-immunoreactive dystrophic neurites are illustrated (arrows, $\boldsymbol{d}$ ). The percentage of area occupied by synaptophysin-positive dystrophic neurites is reported in e. Data are means \pm SEM from nine mice per group. ${ }^{*} p<0.05$, Student's $t$ test; the decrease in dystrophic neurites is significant.

tibody or by phosphatidylinositol-specific phospholipase C (PIPLC) treatment to cleave the GPI-anchored NgR protein from the cells. The binding of A $\beta$ to SKNMC neuroblastoma cells containing endogenous $\mathrm{NgR}$ is also suppressed by anti-NgR antibodies, PI-PLC treatment, and soluble NgR-ectodomain decoy receptor. Thus, NgR provides a high-affinity binding site for APP and $\mathrm{A} \beta$.

\section{$\mathrm{NgR}$ overexpression reduces $\mathrm{A} \boldsymbol{\beta}$ production in neuroblastoma cells}

One of the critical steps in $\mathrm{AD}$ is the proteolytic production of $\mathrm{A} \beta$ from APP. The effect of $\mathrm{NgR}$ on this processing was assessed in N2A neuroblastoma cells stably expressing APPswe (Fig. 5a,b). Conditioned medium from these cells contains a significant level of $A \beta$ (Thinakaran et al., 1996). Expression of endogenous NgR in the N2A cell line is low and undetectable by immunoblots. Overexpression of NgR, but not NgR3, in the APPswe-N2A cells significantly suppresses $\mathrm{A} \beta$ production. $\mathrm{NgR}$ may limit the access of processing secretases to their APP substrate by either direct steric hindrance or an indirect mechanism.

\section{Increased $A \beta$ accumulation in mice lacking NgR}

To examine the significance of the $\mathrm{NgR} /$ APP interaction on APP processing in vivo, the APPswe/PSEN-1( $\triangle \mathrm{E} 9)$ doubletransgenic mouse (Borchelt et al., 1997; Jankowsky et al., 2003) was bred onto a NgR null background (Fig. 6). Brain sections and tissue extracts were examined for $A \beta$ at 6 months of age. Compared with littermate-matched control mice, the absence of $\mathrm{NgR}$ significantly increases the accumulation of both $\mathrm{A} \beta$ plaque and immunoreactive $\mathrm{A} \beta$ (Fig. $6 a-c$ ). The similar elevations in $A \beta_{1-40}$ and $A \beta_{1-42}$ suggest that $\gamma$-secretase site preference is not altered by the absence of $\mathrm{NgR}$.

One consequence of $A \beta$ deposition is the formation of dystrophic neurites in and around plaques. To determine whether NgR absence might alter dystrophic neurite formation separately from $\mathrm{A} \beta$ accumulation, serial sections of the hippocampal dentate gyrus were examined for anti-synaptophysin immunoreactivity (Fig. $6 d, e$ ). The twofold increased A $\beta$ plaque density of the $\mathrm{NgR}^{-/-}$animals is mirrored by a comparable increase in neuritic dystrophy. Thus, NgR modulates neuritic dystrophy in parallel with $A \beta$ levels. We conclude that endogenous $\mathrm{NgR}$ has a role in restricting brain $\mathrm{A} \beta$ accumulation.

\section{$\mathrm{NgR}(310)$ ecto-Fc treatment reduces A $\beta$ plaque deposition}

To increase NgR/APP interactions in vivo, soluble $\mathrm{NgR}(310)$ ecto-Fc protein was infused into APPswe/PSEN-1( $\triangle \mathrm{E} 9)$ double-transgenic mice (Borchelt et al., 1997; Jankowsky et al., 2003). The $\mathrm{NgR}(310)$ ecto-Fc protein contains the entire leucine-rich repeat ligand-binding domain of the NgR fused to the Fc portion of IgG (Lee et al., 2004; Li et al., 2004). To assess the specificity of action of this protein in brain, we examined the distribution of binding sites for $\mathrm{NgR}(310)$ ecto-Fc in wild-type and APPswe/PSEN-1( $\Delta \mathrm{E} 9)$ double-transgenic mouse brain by virtue of the rat $\mathrm{Fc}$ moiety (Fig. 7). The NgR(310)ecto-Fc protein, but not control IgG, associates with myelinated fiber tracts and prominently labels the corpus callosum and intraparenchymal fiber tracts in wild-type brain (Fig. 7a). This is consistent with binding to the previously described myelin ligands of $\mathrm{NgR}$. In transgenic brain, the protein also labels $A \beta$-positive plaques (Fig. $7 b$ ). Whereas control IgG itself exhibits some detectable nonspecific binding for dense $A \beta$ plaques, $\mathrm{NgR}(310)$ ecto-Fc binding is also detectable at the border of plaques in which lower levels of $A \beta$ are found (Fig. $7 c$ ).

$\mathrm{NgR}(310)$ ecto-Fc was administered intracerebroventricularly by continuous infusion from 6- to 8-month-old mice with an Alzet minipump (Alza). Control APPswe/PSEN-1 $(\Delta \mathrm{E} 9)$ mice received rat IgG because both the $\mathrm{NgR}$ and the Fc moiety were of rat origin. The total dose of protein infused was $0.4 \mathrm{mg} /$ mouse over $56 \mathrm{~d}$, corresponding to $0.29 \mathrm{mg} / \mathrm{kg}$ body weight per day. After 
$56 \mathrm{~d}$, mice were killed, and the distribution of $\mathrm{NgR}(310)$ ecto-Fc and rat IgG was assessed (Fig. 8). The pattern of in vivo binding after intracerebroventricular infusion matches that for $\mathrm{NgR}(310)$ ecto-Fc binding to tissue sections. Myelinated tracts are labeled in white matter and in gray matter throughout the forebrain, demonstrating that the infused protein has access to the parenchyma of the brain. Some infused IgG is trapped in dense $A \beta$ plaques, but specific $\mathrm{NgR}(310)$ ecto-Fc binding to the plaque periphery exceeds the nonspecific trapping of control protein.

For these treated mice, brain $\mathrm{A} \beta$ levels were measured by ELISA, and $A \beta$ deposition into amyloid plaques was assessed by anti-A $\beta$ immunohistochemistry. In the $\mathrm{NgR}(310)$ ecto-Fc mice, the deposition of immunoreactive $\mathrm{A} \beta$ into plaque is significantly reduced (Fig. 9a,b). The total level of both $\mathrm{A} \beta_{1-40}$ and $\mathrm{A} \beta_{1-42}$ decreases by $50 \%$ in the brain (Fig. $9 c$ ). The ratio of $\mathrm{A} \beta_{40}$ to $\mathrm{A} \beta_{42}$ is not altered in the treated group, arguing that $\gamma$-secretase function was not significantly modulated by soluble $\mathrm{NgR}$. There is a tight correlation between $\mathrm{A} \beta$ levels and amyloid plaque deposition, suggesting that $\mathrm{NgR}(310)$ ecto-Fc alters $\mathrm{APP} / \mathrm{A} \beta$ metabolism to a greater extent than $A \beta$ aggregation itself (Fig. $9 d$ ).

Because dystrophic neurite formation occurs in and around amyloid plaques and $\mathrm{NgR}$ can regulate neurite growth, we considered whether $\mathrm{NgR}(310)$ ecto-Fc also modulates the formation of dystrophic neurites in APPswe/PSEN-1( $\Delta \mathrm{E} 9)$ mice. In the same group of mice, clusters of dystrophic neurites were identified by antisynaptophysin immunohistology (Fig. $9 e)$. Neuritic plaques are most prominent in the hippocampus, and the area occupied by synaptophysin-positive dystro-

phic neurite clusters is reduced in the $\mathrm{NgR}(310)$ ecto-Fc-treated transgenic mice (Fig. 9f). Microscopically, the morphology of dystrophic neurites formed in $\mathrm{NgR}(310)$ ecto-Fc-treated mice is similar to that in control familial AD (FAD) transgenic mice. Thus, excess NgR protein reduces both neuritic dystrophy and $\mathrm{A} \beta$ plaque deposition in $\mathrm{FAD}$ transgenic mice.

\section{NgR causes parallel changes in $\operatorname{AAPP} \alpha, \operatorname{sAPP} \beta$, and A $\beta$}

One mechanism by which excess NgR could reduce $A \beta$ levels is by preventing $\alpha$ - and $\beta$-secretase access to APP substrate. A prediction from this model is that NgR-induced alterations in $\mathrm{A} \beta$ will be matched by changes in sAPP levels. In contrast, if $\mathrm{NgR}$ were to selectively alter $A \beta$ clearance, then sAPP levels would not change when $\mathrm{NgR}$ levels are manipulated. If increased $\mathrm{NgR}$ were to favor $\alpha$ - over $\beta$-secretase cleavage of APP, then $\operatorname{sAPP} \alpha$ versus sAPP $\beta / A \beta$ levels would exhibit opposite modulation by $\mathrm{NgR}$.

To test these alternatives, we measured the $\alpha$-secretase product $\operatorname{sAPP} \alpha$ by immunoprecipitation and immunoblot after cell culture and in vivo manipulations of $\mathrm{NgR}$ (Fig. 10). The addition of $\mathrm{NgR}(310)$ ecto-Fc to APPswe-N2A cultures results in a reduction in $\operatorname{sAPP} \alpha$ levels in the conditioned medium (Fig. $10 a, b)$. In vivo, brains of $\mathrm{NgR}(310)$ ecto-Fc treated APPswe/ PSEN-1 $(\Delta$ E9) transgenic mice also exhibit decreased sAPP $\alpha$ levels (Fig. 10c,d). These reductions in sAPP $\alpha$ parallel the decreased A $\beta$ level associated with elevated NgR (Figs. 5, 9). Levels of $\operatorname{sAPP} \alpha$ are increased in the brain of APPswe/PSEN-1( $\Delta \mathrm{E} 9)$ transgenic mice lacking $\mathrm{NgR}$ (Fig. $9 e, f$ ), matching the increase of $\mathrm{A} \beta$ levels in these mice (Fig. 6). Levels of sAPP $\beta$ were also assessed in the transgenic mouse brain samples from knock-out mice with an antibody that selectively detects the $C$ terminus of the transgenic sAPP $\beta$ after cleavage by $\beta$-secretase. Genetic ablation of $\mathrm{NgR}$ expression increases SAPP $\beta$, although the magnitude of the increase is not as great as for $\operatorname{sAPP} \alpha$ (Fig. $10 g, h)$. Immunoblot detection of the C-terminal APP fragments (CTF) resulting from $\alpha$ - or $\beta$-secretases revels an increase in $\beta$-CTF levels; $\alpha$-CTF levels could not be quantitated reliably (Fig. 9i,j). Because NgR regulates various APP fragments and A $\beta$ levels in parallel, we conclude that NgR/APP association reduces cleavage of APP by both $\alpha$ - and $\beta$-secretases. 


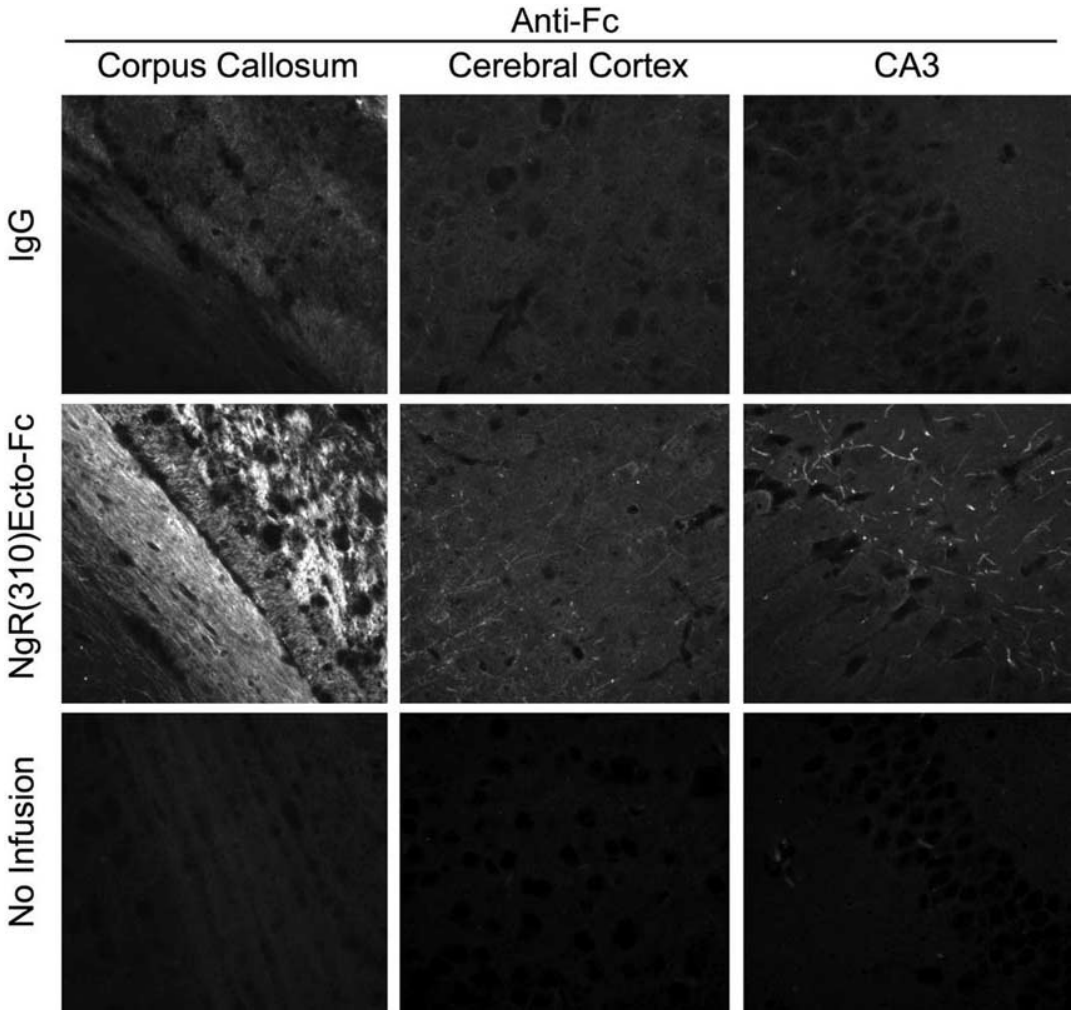

Figure 8. Localization of $\mathrm{NgR}(310)$ ecto-Fc after intracerebroventricular infusion. Brain sections were prepared from APPsw/ PSEN-1 double-transgenic mice of 7 months of age after infusion with rat $\operatorname{lgG}$, rat $\mathrm{NgR}$ (310)ecto-Fc, or no protein. The distribution of the infused protein was detected with fluorescently tagged anti-rat Fc and is similar to that of in vitro protein binding in Figure 6.
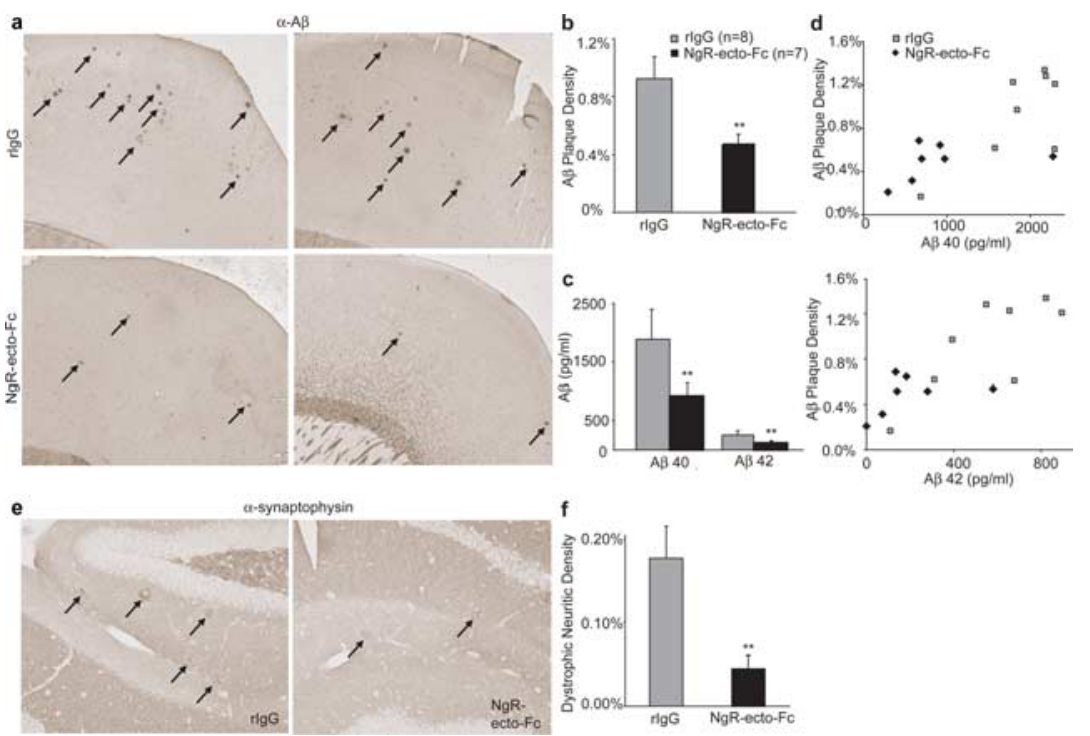

Figure 9. NgR-ecto- $\mathrm{Fc}$ decreases $A \beta$ plaque formation and dystrophic neurites in vivo. Transgenic mice expressing both the human APPswe and PSEN-1( $\Delta$ E9) protein were treated from 6 - 8 months of age with either rat lgG or rat $\mathrm{NgR}(310)$ ecto-Fc from a minipump connected to an intracerebroventricular catheter. Each mouse received $0.4 \mathrm{mg}$ of protein over 2 months $(0.29$ $\left.\mathrm{mg} \cdot \mathrm{kg}^{-1} \cdot \mathrm{d}^{-1}\right), \boldsymbol{a}, \boldsymbol{b}$, Transgenic mice were processed for $A \beta$ immunohistology to reveal amyloid plaque deposition at 8 months of age $(\boldsymbol{a})$. The arrows indicate examples of plaque deposits in sections of the cerebral cortex from three representative mice of eight or seven mice in each group. The area of cerebral cortex occupied by plaque was quantitated (b). Data are means \pm SEM from $n=8$ or 7 mice. The decrease in $A \beta$-positive plaques in the $\mathrm{NgR}(310)$ ecto-Fc group compared with control is significant $\left({ }^{* *} p \leq 0.02\right.$, Student's $t$ test). $c, A \beta$ was measured in formic acid extracts of brain. Data are means \pm SEM from nine animals in each group. The decrease in $A \beta$ in the $\mathrm{NgR}(310)$ ecto-Fc group compared with $\lg \mathrm{G}$ is significant ${ }^{* *} p \leq 0.02$, Student's $t$ test). The ratio of $A \beta_{40}$ to $A \beta_{42}$ is not altered in the $\mathrm{NgR}(310)$ ecto-Fc-treated group. $d$, Correlation of plaque density and $A \beta_{40}$ or $A \beta_{42}$ levels in mice treated as in $\boldsymbol{a}-\boldsymbol{c} . \boldsymbol{e}, \boldsymbol{f}$, Anti-synaptophysin-immunoreactive dystrophic neurites in control and $\mathrm{NgR}(310)$ ecto-Fc-treated transgenic hippocampus are illustrated (arrows, e). The percentage of area occupied by synaptophysin-positive dystrophic neurites is reported in $\boldsymbol{f}$. Data are means \pm SEM from eight or seven mice per group. ${ }^{* *} p<0.02$, Student's $t$ test; the decrease in dystrophic neurites with $\mathrm{NgR}(310)$ ecto-Fc treatment is significant.

\section{Discussion}

Several lines of evidence presented here indicate that the NgR protein plays a significant role in APP/A $\beta$ pathophysiology. Neuronal NgR localization is altered in AD brain. NgR protein physically associates with APP. Endogenous NgR/APP/A $\beta$ interaction serves to suppress the production of $A \beta$ and the $A \beta$ plaque deposition that is characteristic of $\mathrm{AD}$. Alterations of $\mathrm{NgR}$ function by gene targeting or by infusion of soluble $\mathrm{NgR}(310)$ ecto-Fc regulate $\mathrm{A} \beta$ levels in transgenic mouse brain. There is an inverse relationship between the level of $\mathrm{NgR}$ and the level of $\mathrm{A} \beta$, plaque deposits, and neuritic dystrophy. Elimination of $\mathrm{NgR}$ expression increases these measures of $\mathrm{AD}$ activity, whereas treatment with excess soluble $\mathrm{NgR}$ protein reduces $\mathrm{A} \beta$, plaques, and neuritic dystrophy.

The metabolism of APP and A $\beta$ consists of numerous steps that must be considered in explaining the effects of $\mathrm{NgR}$ on $\mathrm{A} \beta$. Certain steps are unlikely to play a significant role based on the current studies. Because $\mathrm{A} \beta$ levels, amyloid plaque deposition, and neuritic dystrophy change in parallel, it is unlikely that $A \beta$ aggregation or the induction of dystrophy is strongly altered by $\mathrm{NgR}$. The extracellular location of $\mathrm{NgR}$ and the absence of any alteration in $\mathrm{A} \beta_{40} / \mathrm{A} \beta_{42}$ ratio with $\mathrm{NgR}$ manipulations argue that $\gamma$-secretase is not a major site of $\mathrm{NgR}$ modulation of APP/A $\beta$ pathology. Exogenous soluble $\mathrm{NgR}(310)$ ecto-Fc appears to enhance endogenous NgR action, acting in opposition to $\mathrm{NgR}$ gene deletion. Therefore, NgR-mediated signaling for axon outgrowth inhibition is unlikely to play a central role for the ability of $\mathrm{NgR}$ to reduce $\mathrm{A} \beta$ pathology. If, instead, NgR signaling within neurons were crucial, then the soluble decoy receptor would have identical (not opposite) effects to those of NgR gene disruption. It is also unlikely that the effects of extracellular $\mathrm{NgR}(310)$ ecto-Fc on $\mathrm{A} \beta$ pathology can be explained primarily by altered intracellular APP trafficking. Could the formation of an $\mathrm{A} \beta$ complex with cell surface endogenous NgR or extracellular NgR(310)ecto-Fc alter the degradation or clearance of the peptide? Specifically, might exogenous NgR(310)ecto-Fc lower A $\beta$ by acting as a "sink" to remove $\mathrm{A} \beta$ in the same manner as does anti-A $\beta$ antibody? The limiting effect of endogenous $\mathrm{NgR}$ on $\mathrm{A} \beta$ pathology and the ability of $\mathrm{NgR}$ overexpression in neuroblastoma cells to reduce $\mathrm{A} \beta$ suggest that a sink hypothesis does not explain the principal action of $\mathrm{NgR}$ on $\mathrm{A} \beta$ pathology. 
a

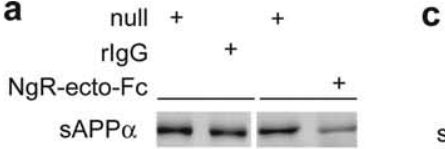

b

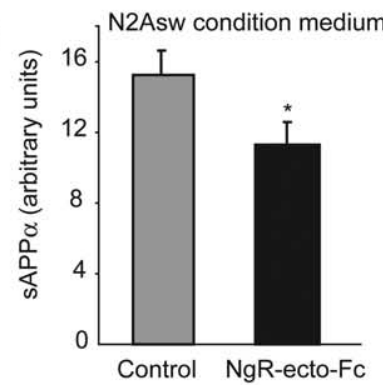

e

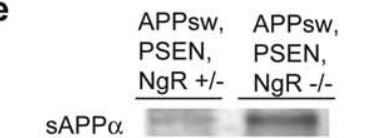

f
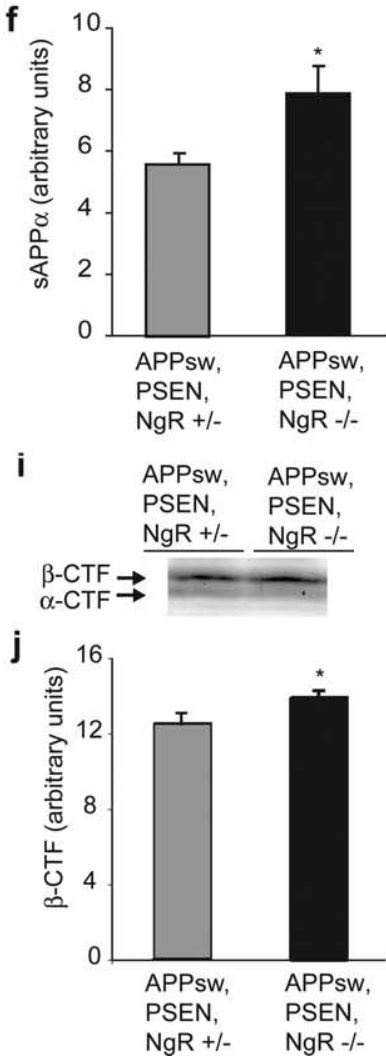

Figure 10. $\mathrm{NgR}$ regulates $\mathrm{SAPP} \alpha$ in parallel with $A \beta$ levels. The level of $\mathrm{SAPP} \alpha$ in brain extracts or N2A culture medium was analyzed by immunoprecipitation with anti-N-terminalAPP 22C11 antibody and immunoblot with anti-A $\beta_{1-17} 6$ E10 antibody. The sAPP $\beta$ fragment was analyzed in brain tissue by direct immunoblots with anti-sAPP $\beta$ swe C-terminal antibody, and the CTFs were detected by the anti-APP-C-terminal 369 antibody. Immunoreactivity per milligram of protein was assessed in independent samples for $n=6-9$ mice or cell cultures in each experimental group (mean \pm SEM; ${ }^{*} p<0.05$ level, ${ }^{* *} p<0.01$, Student's $t$ test). $\boldsymbol{a}, \boldsymbol{b}$ SAPP $\alpha$ levels in conditioned medium from APPswe-expressing N2A cells was quantitated after $48 \mathrm{~h}$ culture in the presence of $1 \mathrm{mg} / \mathrm{ml}$ control rat lg $\mathrm{g}$ or rat $\mathrm{NgR}(310)$ ecto-Fc. c, $\boldsymbol{d}$, sAPP $\alpha$ in brain extracts from APPswe/PSEN-1( $\Delta$ E9) transgenic mice treated from 6-8 months of age with either rat $\lg G$ or rat $\mathrm{NgR}(310)$ ecto-Fc intracerebroventricularly, as in Figure 9. $\boldsymbol{e}, \boldsymbol{f}, \mathrm{SAPP} \alpha$ in brain extracts from 6-month-old littermate-matched mice transgenic for APPswe/PSEN-1( $\Delta E 9)$ and either $\mathrm{NgR}^{+/-}$or $\mathrm{NgR}^{-/-}$, as in Figure 6. $\boldsymbol{g}, \boldsymbol{h}, \mathrm{SAPP} \beta$ in brain extracts from 13-month-old littermate-matched mice transgenic for APPswe/PSEN-1( $\Delta$ E9) and either $N g R^{+/-}$or $N g R^{-/-} . \boldsymbol{i}_{,} \boldsymbol{j}$, $\alpha$-CTF and $\beta$-CTF in brain extracts from 13-month-old littermate-matched mice transgenic for APPswe/PSEN-1( $\Delta$ E9) and either $\mathrm{NgR}^{+/-}$or $\mathrm{Ng}^{-/-}$. The $\beta$-CTF level is quantitated in $j$.
These considerations imply that NgR blockade of initial $\alpha$-secretase and $\beta$-secretase cleavage of APP is likely to be a principal site of NgR action in vivo. Because NgR binds to the extracellular region of APP that serves as a secretase substrate, $\mathrm{NgR}$ might serve as a competitive inhibitor of processing. Alternatively, the APP/NgR interaction may indirectly reduce APP access to secretase compartments in the cell. Consistent with NgRmediated blockade of both $\alpha$ - and $\beta$-secretase access to APP, we found that the levels of the $\operatorname{sAP} \alpha$, sAPP $\beta$, and $\beta$-CTF fragment are altered in parallel with $\mathrm{A} \beta$ levels in $\mathrm{NgR}^{-/-}$mice and $\mathrm{NgR}(310)$ ecto-Fc-treated mice. Together, the data are consistent with the hypothesis that $\mathrm{NgR}$ reduces $\mathrm{A} \beta$ pathology primarily by reducing $\alpha$ - and $\beta$-secretase cleavage.

Apart from $\mathrm{A} \beta$ pathophysiology and $\mathrm{AD}, \mathrm{NgR}$ interactions with APP and A $\beta$ may play roles in normal neuronal physiology. Because APP has been identified as an adaptor for kinesindependent transport of certain cargos in the axon (Kamal et al., 2001), NgR localization to the distal axon may depend on binding to APP. Studies of NgR distribution and function in APP null mice should resolve this issue. Although we did not observe direct competition between $\mathrm{A} \beta$ and Nogo-66, myelin-associated glycoprotein (MAG), or oligodendrocyte myelin glycoprotein for $\mathrm{NgR}$ binding (data not shown), there may be modulatory effects of APP or A $\beta$ on axon growth inhibition by CNS myelin under certain conditions distinct from those examined in preliminary experiments. Because $A \beta$ has been implicated as a regulator of synaptic function recently (Walsh et al., 2002b; Kamenetz et al., 2003), NgR may participate in this modulation directly or indirectly. Overall, the association of APP and NgR tightens the links between axonal function and the neurodegenerative process in AD.

\section{References}

Borchelt DR, Ratovitski T, van Lare J, Lee MK, Gonzales V, Jenkins NA, Copeland NG, Price DL, Sisodia SS (1997) Accelerated amyloid deposition in the brains of transgenic mice coexpressing mutant presenilin 1 and amyloid precursor proteins. Neuron 19:939-945.

Chen MS, Huber AB, van der Haar ME, Frank M, Schnell L, Spillmann AA, Christ F, Schwab ME (2000) Nogo-A is a myelin-associated neurite outgrowth inhibitor and an antigen for monoclonal antibody IN-1. Nature 403:434-439.

Dineley KT, Westerman M, Bui D, Bell K, Ashe KH, Sweatt JD (2001) $\beta$-Amyloid activates the mitogen-activated protein kinase cascade via hippocampal $\alpha 7$ nicotinic acetylcholine receptors: in vitro and in vivo mechanisms related to Alzheimer's disease. J Neurosci 21:4125-4133.

Ehehalt R, Keller P, Haass C, Thiele C, Simons K (2003) Amyloidogenic processing of the Alzheimer beta-amyloid precursor protein depends on lipid rafts. J Cell Biol 160:113-123.

Fournier AE, GrandPre T, Strittmatter SM (2001) Identification of a receptor mediating Nogo-66 inhibition of axonal regeneration. Nature 409:341-346.

Fournier AE, Gould GC, Liu BP, Strittmatter SM (2002) Truncated soluble Nogo receptor binds Nogo- 66 and blocks inhibition of axon growth by myelin. J Neurosci 22:8876-8883.

Gentleman SM, Nash MJ, Sweeting CJ, Graham DI, Roberts GW (1993) Beta-amyloid precursor protein (beta APP) as a marker for axonal injury after head injury. Neurosci Lett 160:139-144.

GrandPre T, Nakamura F, Vartanian T, Strittmatter SM (2000) Identification of the Nogo inhibitor of axon regeneration as a Reticulon protein. Nature 403:439-444.

GrandPre T, Li S, Strittmatter SM (2002) Nogo-66 receptor antagonist peptide promotes axonal regeneration. Nature 417:547-551.

Hardy J, Selkoe DJ (2002) The amyloid hypothesis of Alzheimer's disease: progress and problems on the road to therapeutics. Science 297:353-356

He W, Lu Y, Qahwash I, Hu XY, Chang A, Yan R (2004) Reticulon family members modulate BACE1 activity and amyloid-beta peptide generation. Nat Med 10:959-965.

Jankowsky JL, Xu G, Fromholt D, Gonzales V, Borchelt DR (2003) Environ- 
mental enrichment exacerbates amyloid plaque formation in a transgenic mouse model of Alzheimer disease. J Neuropathol Exp Neurol 62:1220-1227.

Kamal A, Almenar-Queralt A, LeBlanc JF, Roberts EA, Goldstein LS (2001) Kinesin-mediated axonal transport of a membrane compartment containing beta-secretase and presenilin-1 requires APP. Nature 414:643-648.

Kamenetz F, Tomita T, Hsieh H, Seabrook G, Borchelt D, Iwatsubo T, Sisodia S, Malinow R (2003) APP processing and synaptic function. Neuron 37:925-937.

Kim JE, Li S, GrandPre T, Qiu D, Strittmatter SM (2003) Axon regeneration in young adult mice lacking Nogo-A/B. Neuron 38:187-199.

Kim JE, Liu BP, Park JH, Strittmatter SM (2004) Nogo-66 receptor prevents raphespinal and rubrospinal axon regeneration and limits functional recovery from spinal cord injury. Neuron 44:439-451.

Klein WL (2002) Abeta toxicity in Alzheimer's disease: globular oligomers (ADDLs) as new vaccine and drug targets. Neurochem Int 41:345-352.

Kuner P, Schubenel R, Hertel C (1998) Beta-amyloid binds to p57NTR and activates NFkappaB in human neuroblastoma cells. J Neurosci Res 54:798-804.

Lazarov O, Lee M, Peterson DA, Sisodia SS (2002) Evidence that synaptically released $\beta$-amyloid accumulates as extracellular deposits in the hippocampus of transgenic mice. J Neurosci 22:9785-9793.

Lee JK, Kim JE, Sivula M, Strittmatter SM (2004) Nogo receptor antagonism promotes stroke recovery by enhancing axonal plasticity. J Neurosci 24:6209-6217.

Li S, Strittmatter SM (2003) Delayed systemic Nogo-66 receptor antagonist promotes recovery from spinal cord injury. J Neurosci 23:4219-4227.

Li S, Liu BP, Budel S, Li M, Ji B, Walus L, Li W, Jirik A, Rabacchi S, Choi E, Worley D, Sah DW, Pepinsky B, Lee D, Relton J, Strittmatter SM (2004) Blockade of nogo-66, myelin-associated glycoprotein, and oligodendrocyte myelin glycoprotein by soluble nogo-66 receptor promotes axonal sprouting and recovery after spinal injury. J Neurosci 24:10511-10520.

Lombardo JA, Stern EA, McLellan ME, Kajdasz ST, Hickey GA, Bacskai BJ, Hyman BT (2003) Amyloid- $\beta$ antibody treatment leads to rapid normalization of plaque-induced neuritic alterations. J Neurosci 23:10879-10883.

McGee AW, Strittmatter SM (2003) The Nogo-66 receptor: focusing myelin inhibition of axon regeneration. Trends Neurosci 26:193-198.

Nagele RG, D’Andrea MR, Anderson WJ, Wang HY (2002) Intracellular accumulation of beta-amyloid(1-42) in neurons is facilitated by the alpha 7 nicotinic acetylcholine receptor in Alzheimer's disease. Neuroscience 110:199-211.

Otsuka N, Tomonaga M, Ikeda K (1991) Rapid appearance of beta-amyloid precursor protein immunoreactivity in damaged axons and reactive glial cells in rat brain following needle stab injury. Brain Res 568:335-338.

Prinjha R, Moore SE, Vinson M, Blake S, Morrow R, Christie G, Michalovich D, Simmons DL, Walsh FS (2000) Inhibitor of neurite outgrowth in humans. Nature 403:383-384.

Scott JN, Parhad IM, Clark AW (1991) Beta-amyloid precursor protein gene is differentially expressed in axotomized sensory and motor systems. Brain Res Mol Brain Res 10:315-325.

Selkoe DJ, Schenk D (2003) Alzheimer's disease: molecular understanding predicts amyloid-based therapeutics. Annu Rev Pharmacol Toxicol 43:545-584.

Sheng JG, Price DL, Koliatsos VE (2002) Disruption of corticocortical connections ameliorates amyloid burden in terminal fields in a transgenic model of $A \beta$ amyloidosis. J Neurosci 22:9794-9799.

Thinakaran G, Teplow DB, Siman R, Greenberg B, Sisodia SS (1996) Metabolism of the "Swedish" amyloid precursor protein variant in neuro2a (N2a) cells. Evidence that cleavage at the "beta-secretase" site occurs in the golgi apparatus. J Biol Chem 271:9390-9397.

Walsh DM, Klyubin I, Fadeeva JV, Rowan MJ, Selkoe DJ (2002a) Amyloidbeta oligomers: their production, toxicity and therapeutic inhibition. Biochem Soc Trans 30:552-557.

Walsh DM, Klyubin I, Fadeeva JV, Cullen WK, Anwyl R, Wolfe MS, Rowan MJ, Selkoe DJ (2002b) Naturally secreted oligomers of amyloid beta protein potently inhibit hippocampal long-term potentiation in vivo. Nature 416:535-539.

Wang HY, Lee DH, D'Andrea MR, Peterson PA, Shank RP, Reitz AB (2000) beta-Amyloid(1-42) binds to alpha7 nicotinic acetylcholine receptor with high affinity. Implications for Alzheimer's disease pathology. J Biol Chem 275:5626-5632.

Wang X, Chun SJ, Treloar H, Vartanian T, Greer CA, Strittmatter SM (2002) Localization of Nogo-A and Nogo-66 receptor proteins at sites of axonmyelin and synaptic contact. J Neurosci 22:5505-5515.

Yang X, Hyder F, Shulman RG (1996) Activation of single whisker barrel in rat brain localized by functional magnetic resonance imaging. Proc Natl Acad Sci USA 93:475-478. 